\title{
U.S. federal biotech-budget initiative ends
}

Future waShington, D.C.-The Federal Coordinating Council for Science, Engineering, and Technology (FCCSET)-organized under the President's Office of Science and Technology Policy (OSTP, Washingon, DC)-recently published its second annual report on federal biotechnology research and development (R\&D) spending. The report, entitled "Biotechnology for the 21st Century: Realizing the Promise," is a supplement to the fiscal year (FY) 1994 federal budget. Although officials in the Clinton administration offer strong assurances that biotechnology remains a priority, they also say that they will no longer conduct the elaborate annual interagency-budgeting exercises for biotechnology that have been an integral part of these FCCSET reports for the past two years. Future FCCSET reports will focus on "substantive information" about federal biotechnology R\&D programs instead of dollar figures.

The interagency biotechnologybudget exercise has been fraught with other problems. Earlier this year, for example, as the Clinton administration took over from the Bush administration, the upbeat news about Clinton's biotechnology initiative-which increased fed- eral biotechnology R\&Doutlays 6.6 percent over the previous yeartook on an almost surrealistic quality. Details about the FY 1994 budget were missing. Efforts to compare the interagency figures with those supplied by individual agencies revealed inconsistencies. And attempts to reconcile discrepancies often proved frustrating. These problems made the overall message of optimism about federal biotechnology R\&D seem unsettling instead of reassuring.

Other more philosophical problems stalked the federal biotechnology-budget initiative over the past two years. For one thing, definitions of biotechnology varied from agency to agency and even within a single agency. A definition could vary to suit bureaucratic whims, being all inclusive at one moment to demonstrate the strength of a particular program but then narrowing at another moment to show that additional resources were needed.

For another, the fiscal presence of the National Institutes of Health (NIH, Bethesda, MD) inescapably dominated other agencies in the overall federal biotechnology program. Even on the semilogarithmic scale now being used to present dollar figures in the FCCSET re- port, the NIH budget for biotechnology dwarfs that of other agencies. In FY 1994, for instance, the NIH contribution amounts to $\$ 3.3$ billion-about 75 percent-of the overall $\$ 4.3$ billion federal biotechnology initiative.

Clinton administration officials say that they will make the biotechnology component of FCCSET more of a true "planning and coordinating process" and less of an "inventory" process. With the focus in the past being so much on budgeting, the FCCSET biotechnology effort made agency representatives into mere "hurry-up number crunchers," one official notes. "In addition, we weren't free to go outside and integrate with industry, because of the budget information embargo."

Even if the current FCCSET report on the federal biotechnology initiative is the last of its kind, its message is certainly not short on optimism. It states that the initiative's goal is "to sustain and extend U.S. leadership in biotechnology for the 21 st century in order to enhance the quality of life for all Americans and to spur the growth of this important component of a healthy U.S. economy."

-Jefirey L. Fox

\section{Estonia will sell four of its biggest biotech firms}

The four food-processing firms are the cream of the Estonia biotech crop.
HELSINKI-As part of its ongoing privatization plans, the Estonian government is preparing to sell off four of its biggest biotechnology enterprises. The sale-which is being handled by RE Eesti Arastamisettevote (Tallinn, EERE), the agency in charge of privatizing state property--has attracted a number of foreign offers.

Fully 38 percent of the offers are from groups in the U.S., 35 percent are from European groups, 20 percent from Russian groups, and 5 percent from Canadian groups. Less than 2 percent of the offers have come from Estonian enterprises. A final round of bidding, due to take place by year end, will weed out many of these preliminary offers. Indeed, less than 5 percent of preliminary offers make it to the final round, states EERE, which has privatized 48 enterprises since the beginning of 1992 .

"The foreign interest in our biotechnology enterprises has surprised us, since all of them are undercapitalized and, to some degree, still employ Soviet work practices. Development capital is vital if these concerns are to survive," says Robert Stems, EERE's director general.

The four enterprises-all of which are active in food processing-are the cream of the crop, as far as the Estonian biotechology sector is concerned.

- RAS Sailis (Tartu) is a 500employee enterprise with two production facilities that manufacture food enzymes and preservatives. The firm also operates a food-processing unit that produces canned fruit, vegetables, and meat.

- RE Painkula Tarklisete
(Painkula), which employs 500 people, produces food enzymes, preservatives, starch, and starch syrup. It, too, operates a secondary-processing business, producing potato chips and snack foods.

- RAS Salutaguse Parmitehdas (Rapla)-with 53 employees and an annual production capacity of 3,300 tons-produces yeast, molasses, and food enzymes. About $\$ 4$ million is need to modernize production, estimates EERE.

- RAS Tartu Parmitoostus (Tartu)-with 48 employees and an annual production capacity of 3,000 tons-manufactures food enzymes and yeast. EERE estimates that $\$ 2.8$ million worth of capital improvement is needed to turn the business around. Gerard O'Dwyer

Gerard O'Dwyer is a freelance writer in Helsinki. 